\title{
Improved NADH Electroanalysis on Nickel(II) Phthalocyanine Tetrasulfonic Acid/ Calf Thymus Deoxyribonucleic Acid/Reduced Graphene Oxide Composite
}

\author{
Izabela Aparecida L. Ribeiro, ${ }^{a}$ Sakae Yotsumoto-Neto, ${ }^{b}$ Wallans T. P. dos Santos, ${ }^{c}$ \\ Ridvan N. Fernandes, ${ }^{b}$ Marilia O. F. Goulart, ${ }^{d}$ Flavio S. Damos ${ }^{b}$ and Rita de Cássia S. Luz ${ }^{*, b}$ \\ a'Departamento de Química, Universidade Federal dos Vales do Jequitinhonha e Mucuri, \\ Rodovia MGT 367, km 583, 39100-000 Diamantina-MG, Brazil \\ ${ }^{b}$ Departamento de Química, Universidade Federal do Maranhão, 65080-805 São Luís-MA, Brazil \\ ${ }^{c}$ Departamento de Farmácia, Universidade Federal dos Vales do Jequitinhonha e Mucuri, \\ Rodovia MGT 367, km 583, 39100-000 Diamantina-MG, Brazil \\ ${ }^{d}$ Instituto de Química e Biotecnologia, Universidade Federal de Alagoas, \\ Av. Lourival Melo Mota, s/ $n$, Cidade Universitária, 57072-900 Maceió-AL, Brazil
}

\begin{abstract}
This work describes the electrochemical performance of a novel composite based on nickel tetrasulfonated phthalocyanine (NiTsPc), deoxyribonucleic acid from calf thymus (CT-DNA) and reduced graphene oxide ( $\mathrm{rGO}$ ) for the electroanalysis of reduced $\beta$-nicotinamide adenine dinucleotide (NADH), through electrocatalytic oxidation. The modified electrode was denoted as CT-DNA/NiTsPc/rGO. Fourier transform infrared and ultraviolet-visible spectroscopies were performed to characterize the composite material. The electrochemical performance of the composite for NADH oxidation was investigated by cyclic voltammetry (CV), chronoamperometry and differential pulse voltammetry (DPV). The CT-DNA/NiTsPc/rGO modified glassy carbon electrode (GCE) showed an excellent electrocatalytic activity for NADH oxidation with apparent electrocatalytic rate constant $\left(\mathrm{k}_{\mathrm{obs}}\right)$ of $7.35 \times 10^{5} \mathrm{~L} \mathrm{~mol}^{-1} \mathrm{~s}^{-1}$ and linear response range for NADH from 1 up to $1350 \mu \mathrm{mol} \mathrm{L}^{-1}$ for $\mathrm{n}=12(\mathrm{r}=0.999)$. The proposed sensor shows sensitivity, detection limit and quantification limit of $0.014 \mu \mathrm{A} \mathrm{L} \mathrm{mol}^{-1}, 0.3$ and $1 \mu \mathrm{mol} \mathrm{L}^{-1}$, respectively. The prepared sensor was further tested for the determination of NADH in artificial human urine samples, showing promising biomedical applications.
\end{abstract}

Keywords: reduced graphene oxide, CT-DNA, nickel tetrasulfonated phthalocyanine, NADH, electroanalysis, sensor

\section{Introduction}

$\beta$-Nicotinamide adenine dinucleotide in its reduced $(\mathrm{NADH})$ or oxidized form $\left(\mathrm{NAD}^{+}\right)$are ubiquitous biomolecules found in both eukaryotic and prokaryotic organisms. They are coenzymes of great importance in hundreds of natural reactions catalyzed by dehydrogenases. ${ }^{1}$ NADH levels are related to cell proliferation, sickle cell disease, tumor development, neoplasia and ischemia as well as several brain diseases. ${ }^{2}$

Thereby, the electrochemical oxidation of NADH has attracted special attention of many research groups in the field of biosensors development. ${ }^{3}$ In this sense, several methods have been proposed for NADH determination

*e-mail: rita.luz@ufma.br including fluorometric ${ }^{4}$ high performance liquid chromatography (HPLC), ${ }^{5}$ optical, ${ }^{6}$ photoelectrochemical, ${ }^{7}$ electrophoretic ${ }^{8}$ and electrochemical ones. ${ }^{9}$ However, even if chromatographic as well as spectrometric techniques perform better than electrochemistry in terms of selectivity, both require numerous steps, analytical purity reagents, making such analyses very laborious and high cost.

The electrochemical sensors are promising methods for NADH determination since they are cheaper, highly sensitive, easy to construct and do not need highly specialized users. However, the direct oxidation of NADH on several modified electrodes occurs in high overpotentials, which leads generally to passivation of the electrode surface. In order to avoid electrode passivation, researchers have proposed a number of chemically modified substrates with new materials able for electrocatalytic oxidation of NADH. ${ }^{7,10-12}$ 
Nowadays, graphene-based materials have been recognized as a very promising nanomaterial for the development of electrochemical sensors since they show interesting properties including high electrical conductivity, excellent thermal and mechanical properties, susceptibility to chemical modification, ${ }^{13}$ and large surface-to-volume ratio. ${ }^{14-16}$ However, the applications of graphene as platform to the development of sensors is limited by two main aspects, namely: (i) some forms of graphene present low reactivity and cannot be easily dispersed in many solvents ${ }^{17}$ and (ii) they show low ability to promote low potential oxidation of several molecules. ${ }^{18}$ In this sense, two approaches have been suggested to circumvent the limitations in graphene-based materials applications in development of platforms for sensors. The first is based on the use of dispersing agents, such as polymers, biopolymers or surfactants. Among the various biomolecules, DNA has emerged as an interesting alternative to the construction of sets of nanomaterials. The interactions of specific pairing sequence between the complementary chains of DNA may act as a dispersant agent improving the dispersity of the graphene in aqueous medium. ${ }^{19}$ In this sense, DNA can protect the graphene from possible degradations ensuring chemical and thermal stability to the composite material. ${ }^{20-22}$ The second approach to improve graphene electrocatalytic properties is related to the use of molecules with high electrocatalytic capability such as metalo-N4-macrocyclic compounds such as phthalocyanines. ${ }^{23}$ Thus, we have investigated the interaction of a nickel tetrasulfonated phthalocyanine (NiTsPc) with calf thymus DNA (CT-DNA) and graphene.

The nickel phthalocyanine was chosen because these macromolecules are capable to electrocatalyzing several redox reactions, with minimal reorganization energy, and may act as mediators in electrochemical reactions. ${ }^{24}$ In addition, these molecular catalysts show high chemical, mechanical and thermal stability, ${ }^{25}$ and they can adsorb on the surface of graphene without disturbing its electronic configuration. ${ }^{26,27}$

In this sense, the present work reports the development of an electrochemical sensor as a novel and efficient alternative for NADH oxidation and electroanalysis with a wide linear response range at low overpotential using as mediator the hybrid material CT-DNA/NiTsPc/rGO.

\section{Experimental}

\section{Reagents and solutions}

NADH, deoxyribonucleic acid from calf thymus (CT-DNA), graphite oxide, nickel tetrasulfonated phthalocyanine, hydrazine sulfate and 4-(2-hydroxyethyl) piperazine-1-ethanesulfonic acid (HEPES) were purchased from Sigma-Aldrich. Tris (hydroxymethyl) aminomethane (Tris), hydrochloric acid, acetic acid, boric acid, phosphoric acid, sodium perchlorate and sodium hydroxide were purchased from Vetec Fine Chemicals, Rio de Janeiro, Brazil. Dibasic anhydrous sodium phosphate $\left(\mathrm{Na}_{2} \mathrm{HPO}_{4}\right)$ was purchased from Dinâmica Analytical Reagents, São Paulo, Brazil. The reagents used in the experiments were of analytical grade and all solutions were prepared using water purified by the Milli-Q system from Millipore, with resistivity greater than or equal to $18 \mathrm{M} \Omega \mathrm{cm}$.

\section{Apparatus and procedures}

The electrochemical measurements were performed with a potentiostat/galvanostat Autolab model PGSTAT $128 \mathrm{~N}$ from Echo Chemie (Utrecht, The Netherlands) coupled to a computer with the GPES 4.9 software for potential control, acquisition and processing of data. The electrochemical system used to perform the analysis consisted of three electrodes immersed in an electrochemical cell of $10 \mathrm{~mL}$. The working electrode was a glassy carbon with $2 \mathrm{~mm}$ of diameter mounted in Teflon ${ }^{\circledR}$. $\mathrm{An} \mathrm{Ag} / \mathrm{AgCl}_{\text {(sat) }}$ containing $\mathrm{KCl}\left(3 \mathrm{~mol} \mathrm{~L}^{-1}\right)$ was the reference electrode and a platinum wire, an auxiliary electrode. The charge transfer resistance of the sensors were measured by electrochemical impedance spectroscopy (EIS) assays in $1.0 \mathrm{~mol} \mathrm{~L}^{-1}$ $\mathrm{KCl}$ solution containing $1 \mathrm{mmol} \mathrm{L}^{-1}\left[\mathrm{Fe}(\mathrm{CN})_{6}\right]^{3-14-}$ in the frequency range of $10 \mathrm{mHz}-0.1 \mathrm{MHz}$ under $\mathrm{AC}$ amplitude of $10 \mathrm{mV}$ at formal potential. For $\mathrm{pH}$ control of the buffers solutions, $\mathrm{NaOH} 0.2 \mathrm{~mol} \mathrm{~L}^{-1}$ or $\mathrm{HCl} 0.1 \mathrm{~mol} \mathrm{~L}^{-1}$ were used.

Fourier-transform infrared (FTIR) spectra were obtained using a UV-Vis-NIR Cary-5000 spectrometer in the region of $4000-400 \mathrm{~cm}^{-1}$. $\mathrm{KBr}(1 \%)$ tablets were prepared for analysis of the (NiTsPc) complex and the CT-DNA/NiTsPc/rGO composite. UV-Vis spectra of all materials were obtained using an AvaSpec-2048 spectrometer from Avantes. All measurements were carried out in a 10-milimeter optical path quartz cell from Varian. The spectra were recorded on wavelength range of 300 up to $800 \mathrm{~nm}$. All measurements were performed at room temperature $\left(25^{\circ} \mathrm{C}\right)$.

\section{Reduced graphene oxide (rGO) and sensor preparation}

Graphene oxide was prepared according to the literature. ${ }^{18}$ The graphene oxide was reduced chemically with hydrazine and the resulting mixture was filtered and washed to get the reduced graphene oxide (rGO). After this step, $0.5 \mathrm{mg}$ of rGO and $1 \mathrm{mg}$ NiTsPc were dispersed in 
$1 \mathrm{~mL}$ of an aqueous solution containing $2 \mathrm{mg}$ of CT-DNA. The solution was mixed using magnetic stirring and ultrasonic treatment to form a homogeneous mixture. After this step, $7 \mu \mathrm{L}$ of the suspension was added on the electrode surface and dried in an oven for 10 minutes at $60{ }^{\circ} \mathrm{C}$. Finally, the CT-DNA/NiTsPc/rGO modified electrode was washed with distilled water to remove non-adsorbed species and submitted to electrochemical analysis. The modified glassy carbon electrode was denoted as CT-DNA/NiTsPc/ $\mathrm{rGO} / \mathrm{GCE}$.

The electroactive surface area of the CT-DNA/NiTsPc/ rGO/GCE was calculated from Randles-Sevcik theory by using ferricyanide $\left(\mathrm{Fe}\left[(\mathrm{CN})_{6}\right]^{3-}\right)$ as redox probe. ${ }^{28}$ The electroactive area of modified electrode $\left(0.14 \mathrm{~cm}^{2}\right)$ was evaluated from the slope of the plot of peak current versus the square root of scan rate (Figure S1). On the other hand, the heterogeneous apparent transfer rate constant $\left(\mathrm{k}_{\text {app }}\right)$ of the CT-DNA/NiTsPc/rGO/GCE to redox probe $\left(\mathrm{Fe}\left[(\mathrm{CN})_{6}\right]^{3-}\right)$ was evaluated by using electrochemical impedance spectroscopy. ${ }^{29}$

\section{Preparation of samples}

The use of the proposed sensor in artificial urine samples was also investigated by direct analysis of NADH in two different artificial urine samples, described as following: (i) artificial urine was prepared in distilled water with the following constituents and final concentrations: $0.33,0.12,0.016,0.007$ and $0.004 \mathrm{~mol} \mathrm{~L}^{-1}$ of urea, sodium chloride, potassium diphosphate, creatinine and sodium monophosphate, respectively; ${ }^{30}$ (ii) artificial urine was also prepared according to Laube et al. ${ }^{31}$ The solution contains the following constituents and final concentrations: $0.411 \mathrm{~mol} \mathrm{~L}^{-1}$ urea, $0.0268 \mathrm{~mol} \mathrm{~L}^{-1}$ potassium chloride, $3 \mathrm{~g} \mathrm{~L}^{-1}$ sodium chloride and 0.0513, 0.014, 0.0186 and $0.0068 \mathrm{~mol} \mathrm{~L}^{-1}$ of sodium sulfate, potassium phosphate, ammonium choride and dihydrated calcium chloride, respectively. In both procedures, the $\mathrm{pH}$ value of the sample solution was $6.6( \pm 0.1)$. The voltammetric measurements were carried out for the recovery tests to determine NADH in the artificial human urine samples.

\section{Results and Discussion}

Characterization of composite NiTsPc/rGO by infrared spectroscopy and characterization of NiTsPc and CT-DNA by UV-Vis spectroscopy

Fourier transform infrared spectroscopy (FTIR) measurements were carried out to examine possible interactions between reduced graphene oxide and the
nickel-N4 macrocyclic complex (NiTsPc). FTIR spectra were obtained for reduced graphene oxide, NiTsPc and composite NiTsPc/rGO (Figure 1). The FTIR spectrum presented in Figure 1a shows a broad band at $3446 \mathrm{~cm}^{-1}$, which can be associated to the stretching of $\mathrm{OH}$ group. The peak observed at $1548 \mathrm{~cm}^{-1}$ is due to $\mathrm{C}=\mathrm{C}$ stretching, which is common in this region and can also be attributed to deformities of the $\mathrm{O}-\mathrm{H}$ groups. The bands located in the region between 1500 and $900 \mathrm{~cm}^{-1}$ are possibly assigned to stretching and strains of $\mathrm{C}^{-} \mathrm{O}$ bonds as well as to deformations in the $\mathrm{O}-\mathrm{H}$ bond. . $^{32,33}$

The spectrum obtained for NiTsPc complex (Figure 1b) shows bands between 650 and $812 \mathrm{~cm}^{-1}$ related to deformations of $\mathrm{C}-\mathrm{H}$ bonds. The peaks located at 1031 and $1328 \mathrm{~cm}^{-1}$ refer to the stretching of the SO group and of the isoindol group, respectively. ${ }^{34-36}$

The spectrum obtained for the NiTsPc/rGO composite (Figure 1c) confirms the modification of rGO with the nickel-N4 macrocyclic by adsorption, since the peaks related to the complex and the graphene shown in Figures $1 \mathrm{a}$ and $1 \mathrm{~b}$ were verified in the composite spectra.

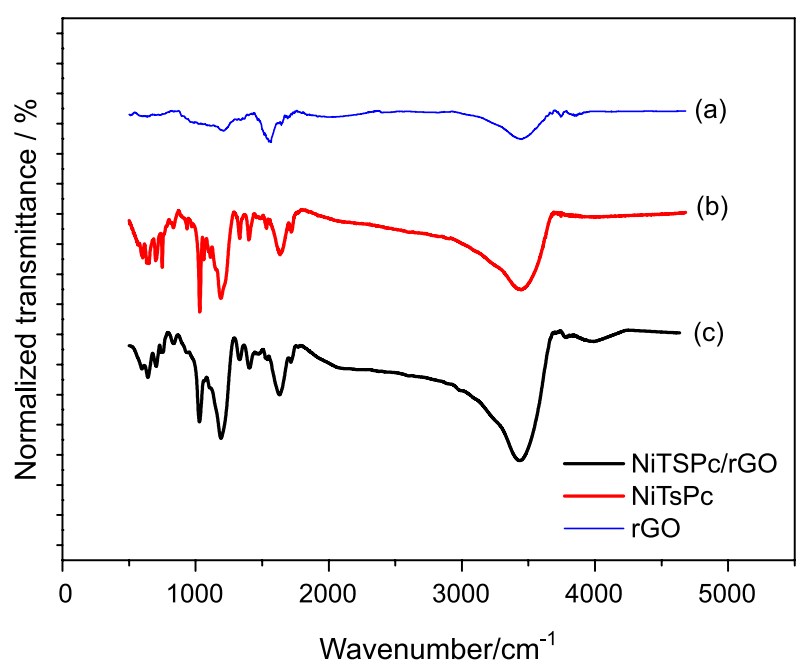

Figure 1. FTIR spectra for (a) reduced graphene oxide; (b) NiTsPc and (c) NiTsPc/rGO.

The interaction between NiTsPc and CT-DNA was also accompanied by UV-Vis spectroscopy. The absorption spectrum of NiTsPc shows two absorption bands. The former, B band (or Soret), at approximately $340 \mathrm{~nm}$ $\left(\mathrm{a}_{2 \mathrm{u}}(\pi) \rightarrow \mathrm{e}_{\mathrm{g}}\left(\pi^{*}\right)\right)^{37}$ appears in the UV region and the later, Q-band, between 600 and $700 \mathrm{~nm}\left(\mathrm{a}_{1 \mathrm{u}}(\pi) \rightarrow \mathrm{e}_{\mathrm{g}}\left(\pi^{*}\right)\right)^{37}$ in the visible region of spectrum (Figure 2, black line). The Q-band shows a sharper peak with maximum at $669 \mathrm{~nm}$ as well as a weaker peak with maximum at $607 \mathrm{~nm}$.

Figure 2 (spectra 2-3) show the interaction of NiTsPc with CT-DNA. The results show that the presence of CT-DNA promotes a decrease of the Q-band intensity at 
$669 \mathrm{~nm}$. A considerable hypochromicity without red-shift in the Q-band of phthalocyanine is caused by its interaction with the DNA surface.

Thereby, the nickel(II) center of phthalocyanine is presumably coordinated by the carbonyl group of thymine or nitrogen-containing ring of the base pairs. The interaction between metallic phthalocyanines and DNA has been reported in the literature by other research groups. ${ }^{38-40}$

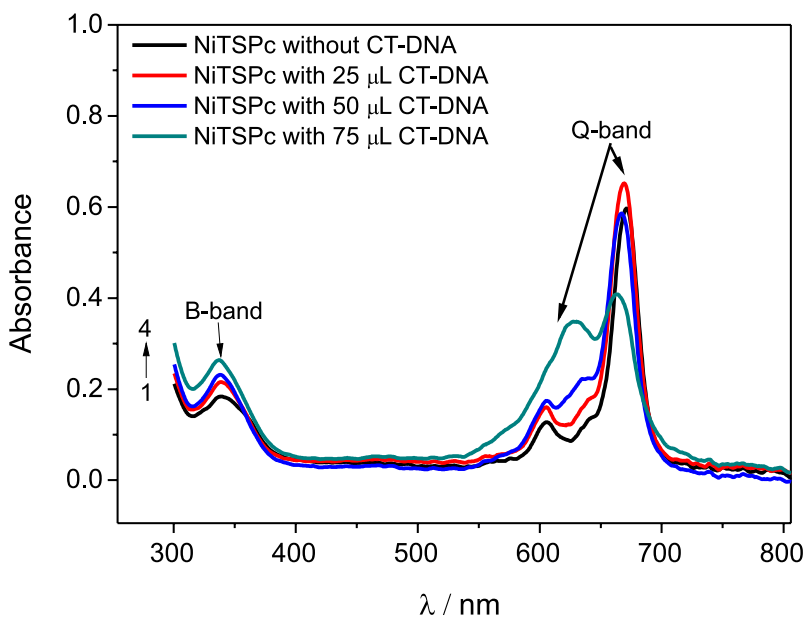

Figure 2. UV-Vis spectra of NiTsPc $\left(10 \mu \mathrm{mol} \mathrm{L}^{-1}\right.$ in water/DMSO $)$ in the absence (spectrum 1) and presence of 25 and $75 \mu \mathrm{L}$ (spectra 2 and 3) of CT-DNA aqueous solution $\left(0.01 \mathrm{~g} \mathrm{~L}^{-1}\right)$.

Electrochemical characterization of the CT-DNA/NiTsPc/ rGO modified electrode

In order to characterize the electrochemical performance of the sensor, electrochemical impedance studies were performed in ferricyanide as redox probe. Figure S2 shows the Nyquist plot for CT-DNA/NiTsPc/rGO modified electrode in a solution containing $5 \mathrm{mmol} \mathrm{L}^{-1}\left[\mathrm{Fe}(\mathrm{CN})_{6}\right]^{3-}$ in $1.0 \mathrm{~mol} \mathrm{~L}^{-1} \mathrm{KCl}$. The semicircle shown in Figure S2 clearly indicates that charge transfer is kinetically controlled. We obtained from the diameter of the semicircle a $\mathrm{R}_{\mathrm{ct}}$ equal to $112.16 \Omega$ for the $\mathrm{Fe}\left[(\mathrm{CN})_{6}\right]^{3-}$ redox processes on CT-DNA/NiTsPc/rGO modified electrode. For the bare electrode a $R_{c t}$ of $500 \Omega$ was found. The electron transfer rate constants $\left(\mathrm{k}_{\text {app }}\right)$ of the redox probe at modified GCE and bare GCE were calculated according to the following expression: ${ }^{29}$

$\mathrm{k}_{\text {app }}=\frac{\mathrm{RT}}{\mathrm{n}^{2} \mathrm{~F}^{2} \mathrm{AR}_{\mathrm{ct}} \mathrm{C}}$

where $\mathrm{A}$ is the geometric area of the electrode, $\mathrm{C}$ is the bulk concentration of the $\left[\mathrm{Fe}(\mathrm{CN})_{6}\right]^{3-}\left(\mathrm{mol} \mathrm{cm}^{-3}\right), \mathrm{R}_{\mathrm{ct}}$ is the charge transfer resistance, and $\mathrm{R}, \mathrm{T}, \mathrm{n}$ and $\mathrm{F}$ have their usual meanings. The value of $\mathrm{k}_{\mathrm{ap}}$ found was $6.68 \times 10^{-3} \mathrm{~cm} \mathrm{~s}^{-1}$ for the modified electrode and $1.50 \times 10^{-3} \mathrm{~cm} \mathrm{~s}^{-1}$ for bare electrode. It is worth noting that the presence of the composite (CT-DNA/NiTsPc/rGO) enhances the rate constant by 4.5 -fold, suggesting that it presents high electronic transfer constant in comparison to bare electrode.

In addition, cyclic voltammograms (CVs) were carried out in the absence and in the presence of $200 \mu \mathrm{mol} \mathrm{L}^{-1}$ NADH (Figure 3) and they were analyzed in comparison to the voltammograms obtained for each of the surface modifiers in the presence of $200 \mu \mathrm{mol} \mathrm{L} \mathrm{L}^{-1} \mathrm{NADH}$.

The CV obtained for the CT-DNA/NiTsPc/rGO modified electrode in absence of NADH (Figure 3, curve 1) shows no redox process in phosphate buffer solution ( $\mathrm{pH}$ 7.0). In fact, the nickel tetrasulfonated phthalocyanine, when immobilized on the surface of an electrode, presents a redox couple, in solutions with $\mathrm{pH}$ values near to 12 . On the other hand, the Ni-complex does not show redox pair when electrolyte solutions with $\mathrm{pH}$ values below 12 are employed. However, neutral solutions do not preclude the ability of nickel phthalocyanines to catalyze redox reactions. ${ }^{41,42}$

Figure 3 (curve 2) shows the CV on the bare GCE in the presence of $200 \mu \mathrm{mol} \mathrm{L}^{-1} \mathrm{NADH}$. The NADH oxidation on bare GCE resulted in a low peak current with high oxidation potential of about $800 \mathrm{mV} v s . \mathrm{Ag} / \mathrm{AgCl}$. Figure 3 (curve 3) refers to NADH oxidation $\left(200 \mu \mathrm{mol} \mathrm{L}^{-1}\right)$ on the electrode modified with CT-DNA. As can be seen, the NADH oxidation potential was about $130 \mathrm{mV} v s . \mathrm{Ag} / \mathrm{AgCl}$ lower than that observed with the unmodified electrode (curve 2), which can be consequence of interaction between CT-DNA and NADH, causing a shift in the oxidation potential of the analyte to a less positive potential. On the other hand, the electrode modified with CT-DNA shows a smaller peak current compared with bare electrode, suggesting a slight resistance to the charge transfer process between the electrode and analyte.

Figure 3 (curve 4) shows the NADH oxidation $\left(200 \mu \mathrm{mol} \mathrm{L}{ }^{-1}\right)$ on the modified electrode with rGO. The oxidation of the analyte occurs at potential near $670 \mathrm{mV} v s . \mathrm{Ag} / \mathrm{AgCl}$. However, the anodic current obtained for NADH oxidation on the rGO modified electrode (curve 4) is higher and more defined than that obtained when the electrode was modified with CT-DNA (curve 3), suggesting a good electronic transfer between $\mathrm{rGO}$ and NADH. The curve 5 of Figure 3 shows oxidation of NADH $\left(200 \mu \mathrm{mol} \mathrm{L} \mathrm{L}^{-1}\right)$ on the NiTsPc complex-modified electrode. The anodic peak potential of NADH occurs at about $560 \mathrm{mV} v s . \mathrm{Ag} / \mathrm{AgCl}$ enabling a reduction of $240 \mathrm{mV}$ NADH oxidation potential in comparison to that with unmodified electrode (Figure 3, curve 2). This result suggests that the nickel macrocyclic complex exhibits excellent electrocatalytic ability toward NADH oxidation. 
The curve 6 of Figure 3 shows the voltammetric profile of NADH oxidation $\left(200 \mu \mathrm{mol} \mathrm{L}^{-1}\right)$ on the CT-DNA/NiTsPc/rGO modified electrode. As can be seen, the NADH oxidation potential was reduced to $240 \mathrm{mV} v s$. $\mathrm{Ag} / \mathrm{AgCl}$ with a significant increase in anodic current in comparison to NADH oxidation on unmodified electrode (Figure 3, curve 2).

The higher anodic current of NADH on CT-DNA/ NiTsPc/rGO can be attributed to the low resistance to charge transfer of the composite NiTSPc/rGO, as well as good dispersion, fixation and stability of graphene and nickel complex on the electrode surface promoted by CT-DNA. ${ }^{19,20}$ These results suggest that the composite material properties come from synergistic effects among the nickel complex, rGO and CT-DNA.

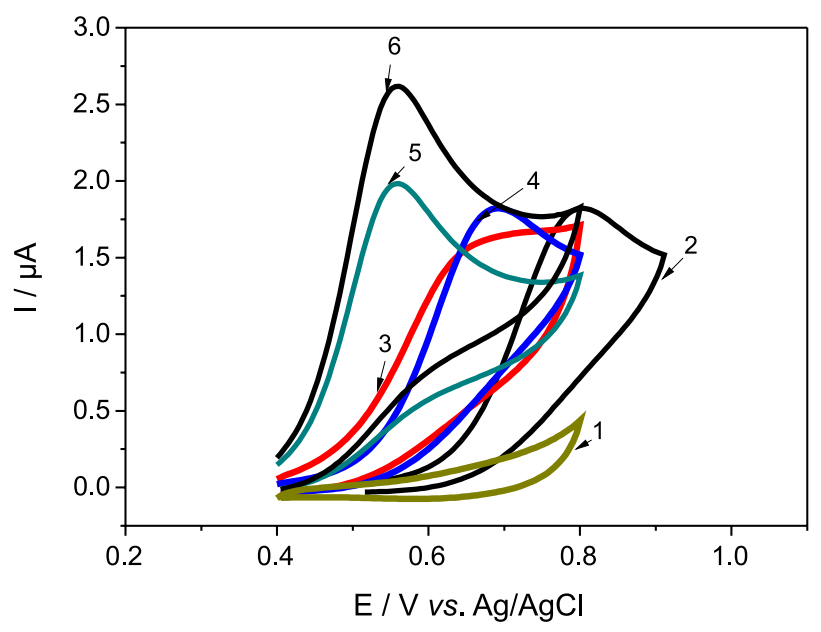

Figure 3. $\mathrm{CV}$ s of the GCE modified with CT-DNA/NiTsPc/rGO in the absence of NADH (curve 1); CVs on the bare electrode, in the presence of NADH (curve 2) and $\mathrm{CV}$ of the modified electrode with: CT-DNA (curve 3); rGO (curve 4); NiTsPc (curve 5) and modified CT-DNA/NiTsPc/rGO (curve 6). Experimental conditions: $200 \mu \mathrm{mol} \mathrm{L}^{-1}$ $\mathrm{NADH}$ in $0.1 \mathrm{~mol} \mathrm{~L}^{-1}$ phosphate buffer $\mathrm{pH} 7.0$, scan rate of $0.05 \mathrm{~V} \mathrm{~s}^{-1}$.

Figure 4 shows cyclic voltammograms for CT-DNA/ NiTsPc/rGO in presence of different concentrations of NADH in $0.1 \mathrm{~mol} \mathrm{~L}^{-1}$ phosphate buffer $\mathrm{pH}$ 7.0. As can be seen, the peak current for NADH oxidation depends on NADH concentration (inset of Figure 4), suggesting that the CT-DNA/NiTsPc/rGO modified electrode can be successfully applied for NADH detection. Thus, the peak current for NADH oxidation was evaluated in more details to obtain new insights about the electrocatalytic processes on the sensor surface.

Electrocatalytic oxidation of $\mathrm{NADH}$ on CT-DNA/NiTsPc/ rGO/GCE

Cyclic voltammograms and amperograms were also performed to analyse the electrocatalytic oxidation of

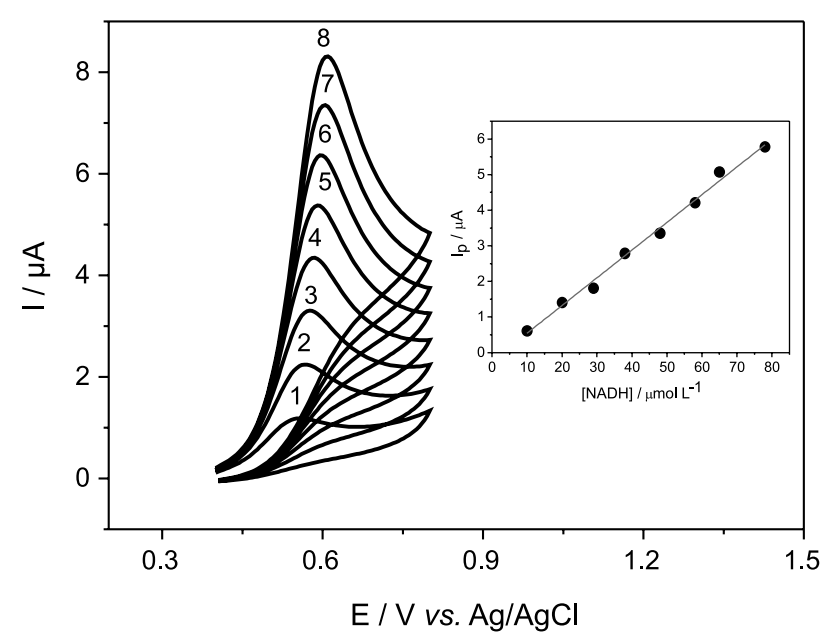

Figure 4. $\mathrm{CV}$ s related to oxidation of NADH at the following concentrations: (1) 10; (2) 20; (3) 30; (4) 38; (5) 48; (6) 57; (7) 65 and (8) $78 \mu \mathrm{mol} \mathrm{L}^{-1}$. Figure inserted: plot of $\mathrm{I}_{\mathrm{p}} v s$. [NADH].

NADH on CT-DNA/NiTsPc/rGO/GCE. Figure 5A shows CV obtained for NADH $\left(200 \mu \mathrm{mol} \mathrm{L} \mathrm{L}^{-1}\right)$ oxidation on CT-DNA/NiTsPc/rGO/GCE at different scan rates. The plot of $\mathrm{I}_{\mathrm{p}} v s . v^{1 / 2}$ (Figure 5B) shows a linear relationship, which suggests a diffusion-controlled NADH oxidation process on the composite modified electrode. ${ }^{28}$ As can be seen in Figure $5 \mathrm{~A}, \mathrm{CV}$ s of NADH on modified electrode present only the anodic peak in the investigated potential range, which is typical of totally irreversible systems. ${ }^{28}$

Assuming an irreversible oxidation, the following equation was employed to find the number of electrons for NADH oxidation: ${ }^{28}$

$\mathrm{I}_{\mathrm{p}}=\left(2.99 \times 10^{5}\right)\left[(1-\alpha) \mathrm{n}_{\mathrm{a}}\right]^{\frac{1}{2}} \mathrm{nAC}_{\mathrm{o}}^{*} \mathrm{D}_{\mathrm{o}}^{\frac{1}{2}} v^{\frac{1}{2}}$

where $I_{p}$ is the peak current, $n$ is the total number of electrons involved in the reaction, $\alpha$ is the coefficient of electron transfer, $n_{a}$ is the number of electrons involved in the determining step of the reaction, $D_{0}$ is the diffusion coefficient of the electroactive species $\left(2.4 \times 10^{-6} \mathrm{~cm}^{2} \mathrm{~s}^{-1}\right),{ }^{43}$ $\mathrm{A}$ is the area of the electrode, $\mathrm{C}_{\mathrm{o}}{ }^{*}$ is the concentration of electroactive species within the solution $\left(\mathrm{mol} \mathrm{cm}^{-3}\right)$ and $\mathrm{v}$, the scan rate.

The value of $(1-\alpha) n_{a}$ for NADH oxidation was calculated according to the following equation: ${ }^{28}$

$(1-\alpha) n_{a}=\frac{47.7 m V}{E_{p}-E_{p / 2}}$

where $E_{p}$ is the potential peak and $E_{p / 2}$ the potential at the half height of the peak current. The value of $(1-\alpha) n_{a}$ was 0.72 . In this sense, the value of $(1-\alpha) n_{a}$ from equation 3 was inserted in equation 2 to give a value of $n$ of 1.7 , which suggests that the total number of electrons involved in 

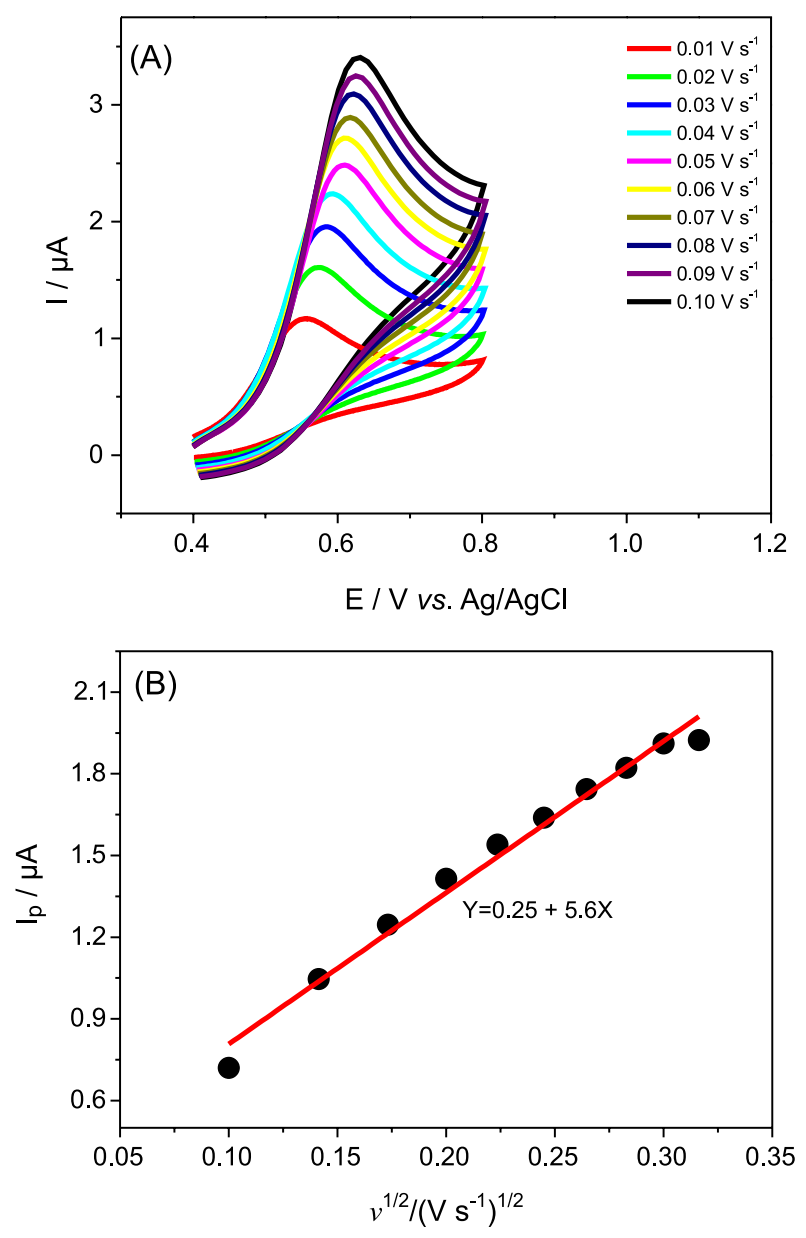

Figure 5. (A) CV obtained for GCE modified with CT-DNA/NiTsPc/rGO in $\mathrm{pH} 7.0$ phosphate buffer in scan rate (1) $0.01 \mathrm{~V} \mathrm{~s}^{-1}$ to (10) $0.10 \mathrm{~V} \mathrm{~s}^{-1}$; (B) plot of peak current $\left(\mathrm{I}_{\mathrm{p}}\right)$ versus the square root of scan rate, $\mathrm{v}$ is varying from 0.01 to $0.10 \mathrm{~V} \mathrm{~s}^{-1}$ in the presence of $200 \mu \mathrm{mol} \mathrm{L}^{-1} \mathrm{NADH}$ in $0.1 \mathrm{~mol} \mathrm{~L}^{-1}$ phosphate buffer $\mathrm{pH}$ 7.0.

the electron transfer process between the analyte and the modified electrode is about 2 electrons. This value is similar to that determined by other researchers. ${ }^{1,43,44}$

The electrocatalytic oxidation of NADH on the surface of CT-DNA/NiTsPc/rGO modified electrode was also verified by chronoamperometry. Figure $6 \mathrm{~A}$ shows the plot of limiting current $\left(\mathrm{I}_{\mathrm{lim}}\right) v s$. the inverse of the square root of the time $\left(\mathrm{t}^{-1 / 2}\right)$ for modified electrode in presence of different concentrations of NADH (50, 100, 150, 200

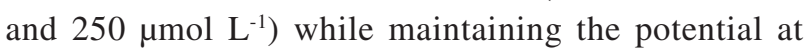
$0.56 \mathrm{~V} \mathrm{vs}$. $\mathrm{Ag} / \mathrm{AgCl}$. The amperograms are inserted in Figure 6A.

The plot of $\mathrm{I}_{\text {lim }} v s . \mathrm{t}^{-1 / 2}$ (Figure 6A) confirms that the observed currents are controlled by diffusion of NADH from solution to electrode surface. Thus, the corresponding current of the electrochemical reaction follows the Cottrell equation: ${ }^{28}$

$\mathrm{I}_{\mathrm{lim}}=\mathrm{nFA} \mathrm{D}_{\mathrm{o}}^{1 / 2} \mathrm{C}_{\mathrm{o}} \pi^{-1 / 2} \mathrm{t}^{-1 / 2}$
Based on the equation 4 , the graph I vs. $\mathrm{t}^{-1 / 2}$ presents a linear behavior for NADH concentrations between 50 and $250 \mu \mathrm{mol} \mathrm{L}^{-1}$ (Figure 6B). Taken into account that NADH is oxidized to $\mathrm{NAD}^{+}$via 2 electrons, ${ }^{1,43,44}$ the average diffusion coefficient was $3.30 \times 10^{-6} \mathrm{~cm}^{2} \mathrm{~s}^{-1}$, which is in agreement with the value determined by $\mathrm{CV}$ in this work.

Chronoamperometry can be utilized for the evaluation of the apparent electrocatalytic rate constant $\left(\mathrm{k}_{\mathrm{obs}}\right)$ between the NADH and redox sites of the CT-DNA/NiTsPc/rGO modified electrode based on the following equation: ${ }^{28}$

$\mathrm{I}_{\text {cat }} / \mathrm{I}_{\lim }=\gamma^{1 / 2}\left[\pi^{1 / 2} \operatorname{erf}\left(\gamma^{1 / 2}\right)+\exp (-\gamma) / \gamma^{1 / 2}\right]$

where catalytic current $\left(\mathrm{I}_{\text {cat }}\right)$ and $\mathrm{I}_{\text {lim }}$ are the currents of the CT-DNA/NiTsPc/rGO/GCE in the presence and absence of $\mathrm{NADH}$, respectively. $\mathrm{C}_{\mathrm{o}}$ is the concentration of $\mathrm{NADH}$ in mol L-1, $\gamma=\mathrm{k}_{\mathrm{obs}} \mathrm{C}_{\mathrm{o}} \mathrm{t}$ and erf $\left(\gamma^{1 / 2}\right)$ is the error function.

In cases where $\gamma$ exceeds the value of 2 , the error function $\left(\operatorname{erf}\left(\gamma^{1 / 2}\right)\right)$ is almost equal to unity and therefore, the above equation can be reduced to:

$\mathrm{I}_{\mathrm{cat}} / \mathrm{I}_{\lim }=\gamma^{1 / 2} \pi^{1 / 2}=\left(\mathrm{k}_{\mathrm{obs}} \mathrm{C}_{\mathrm{o}} \pi\right)^{1 / 2} \mathrm{t}^{1 / 2}$

where $\mathrm{k}_{\mathrm{obs}}$ is the apparent electrocatalytic rate constant $\left(\mathrm{L} \mathrm{mol}^{-1} \mathrm{~s}^{-1}\right)$ and $\mathrm{t}$ is the elapsed time (s). From the slope of the plot of $\mathrm{I}_{\text {cat }} / \mathrm{I}_{\text {lim }} v s . \mathrm{t}^{1 / 2}$ (Figure $6 \mathrm{C}$ ), it was possible to calculate the $\mathrm{k}_{\mathrm{obs}}$ value for $\mathrm{NADH}$ concentrations in the

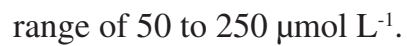

From the values of the slopes, the average value of $\mathrm{k}$ was found to be $7.35 \times 10^{5} \mathrm{~L} \mathrm{~mol}^{-1} \mathrm{~s}^{-1}$. The average $\mathrm{k}_{\mathrm{obs}}$ value estimated from plot of $I_{c a t} / I_{L} v s$. $t^{1 / 2}$ represents a higher electrocatalytic rate constant, in comparison with other electrodes for NADH detection (Table 1), suggesting that the electronic transfer process for NADH oxidation on CT-DNA/NiTsPc/rGO/GCE is very fast.

Influence of the concentrations of $\mathrm{rGO}, \mathrm{NiTsPc}$, and $\mathrm{pH}$ on the electrochemical oxidation of NADH

The response of the CT-DNA/NiTsPc/rGO can be affected by DNA, rGO, and NiTsPc concentrations. The concentration of CT-DNA was kept constant at $2 \mathrm{mg} \mathrm{mL}^{-1}$ for all subsequent experiments, since CT-DNA concentrations higher than $2 \mathrm{mg} \mathrm{mL}^{-1}$ resulted in films with low responses toward $\mathrm{NADH}$. On the other hand, films prepared with CT-DNA concentrations lower than $2 \mathrm{mg} \mathrm{mL}^{-1}$ leach out of the electrode surface.

CVs on the electrode modified with several concentrations of rGO and NiTsPc were performed in the presence of $200 \mu \mathrm{mol} \mathrm{L}-1 \mathrm{NADH}$, in order to obtain 

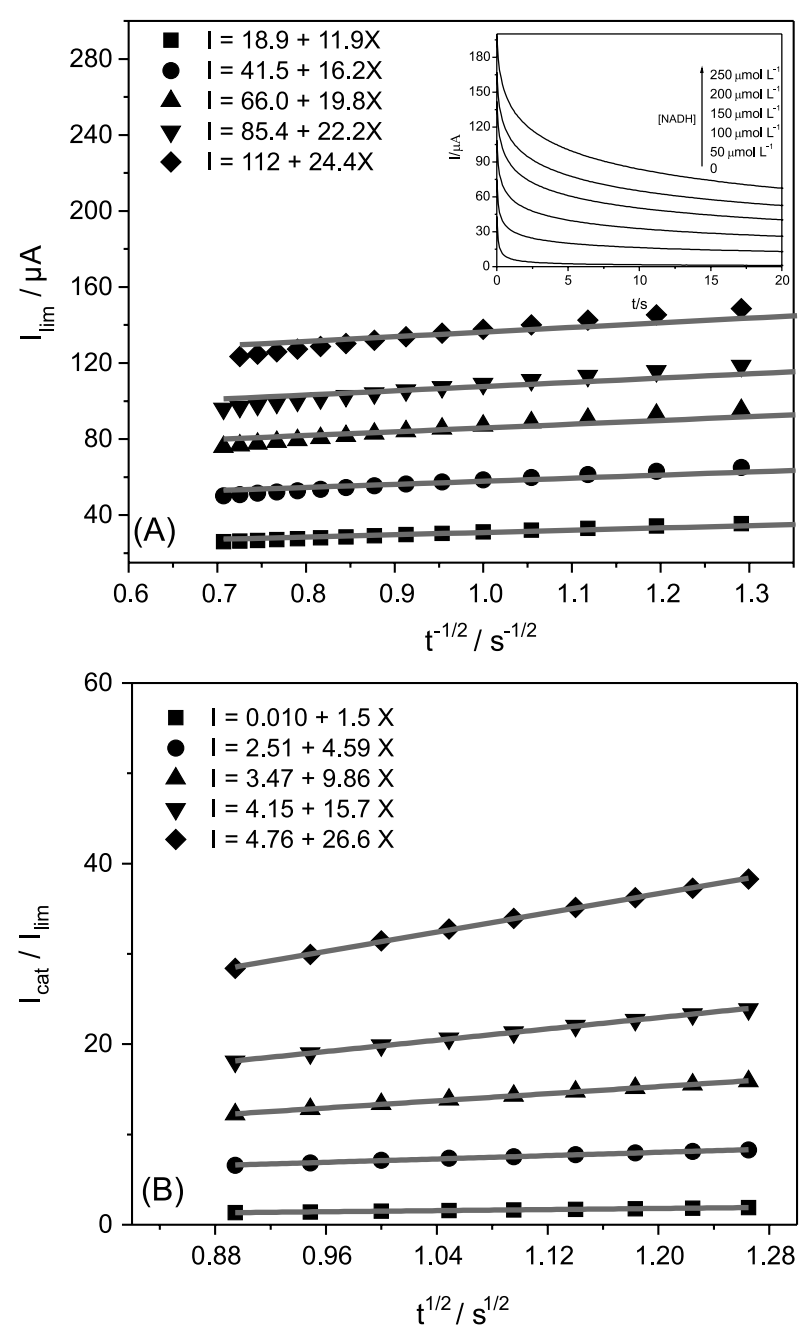

Figure 6. (A) Plot of I vs. $\mathrm{t}^{-1 / 2}$. Insert in (A): Chronoamperograms for different concentrations of NADH $\left(50,100,150,200\right.$ and $260 \mu \mathrm{mol} \mathrm{L}^{-1}$ $\mathrm{NADH}$ ) in a fixed potential of $0.56 \mathrm{~V} v s$. $\mathrm{Ag} / \mathrm{AgCl}$. (B) Plot of $\mathrm{I}_{\text {cal }} / \mathrm{I}_{\text {lim }} v s . \mathrm{t}^{1 / 2}$. Experiments carried in $0.1 \mathrm{~mol} \mathrm{~L}^{-1}$ phosphate buffer solution (pH 7.0) for 20 seconds.

the optimal concentrations of rGO and NiTsPc for the electrochemical oxidation of NADH on CT-DNA/NiTsPc/ $\mathrm{rGO} / \mathrm{GCE}$.

The amount of rGO on the surface of GCE was controlled by using the same volume of the suspension with different concentrations of $\mathrm{rGO}(0.5,0.75,1.0$, and $\left.1.5 \mathrm{mg} \mathrm{mL}^{-1}\right)$, maintaining the CT-DNA $\left(2 \mathrm{mg} \mathrm{mL}^{-1}\right)$ and NiTsPc $\left(10.0 \mathrm{mmol} \mathrm{L}^{-1}\right)$ concentrations.

The effect of the rGO amount on the sensor response is shown in Table 2. As can be seen, the peak current for NADH oxidation decreases with the increase of rGO concentration. Films prepared with rGO concentrations lower than $0.5 \mathrm{mg} \mathrm{mL}^{-1}$ presented low stability. In this sense, the rGO concentration was kept at $0.5 \mathrm{mg} \mathrm{mL}^{-1}$ for all subsequent measurements in order to find the better stability of the film and response toward NADH oxidation.

The NiTsPc concentration also affects the sensor response (Table 2). As can be seen in Table 2, the anodic peak current toward NADH oxidation increased when the macrocyclic concentration increased from 0.1 to $1.0 \mathrm{mmol} \mathrm{L}^{-1}$. Sensors constructed from solutions with NiTsPc concentrations lower than $1.0 \mathrm{mmol} \mathrm{L}^{-1}$ showed low peak currents toward NADH oxidation. In addition, sensors prepared with NiTsPc concentrations higher than $1.0 \mathrm{mmol} \mathrm{L}^{-1}$ were also inefficient to provoke the electrocatalysis of the NADH oxidation. Then, all subsequent sensors were prepared with $1.0 \mathrm{mmol} \mathrm{L}^{-1}$ of Ni-complex, $2 \mathrm{mg} \mathrm{mL}^{-1}$ of CT-DNA, and $0.5 \mathrm{mg} \mathrm{mL}^{-1}$ of rGO.

The influence of the solution $\mathrm{pH}$ on the electrochemical response of NADH was also investigated for $0.1 \mathrm{~mol} \mathrm{~L}^{-1}$ PBS buffer solutions with $\mathrm{pH}$ between 5.0 and 8.5 (Figure S3). The experimental results indicate that $\mathrm{pH}$ has a significant influence on the values of the anodic peak potential. According to Figure S3, the anodic peak potential $\left(\mathrm{E}_{\mathrm{pa}}\right)$ shifted to more negative potentials with an increase of $\mathrm{pH}$ value from 5.0 to 7.0. The $\mathrm{E}_{\mathrm{pa}}$ values shift linearly with changes in $\mathrm{pH}$ values with a correlation coefficient of 0.998 . The linear correlation obtained between $\mathrm{pH}$ values of 5.0 to 7.0 showed a slope of $-22.68 \mathrm{mV} / \mathrm{pH}$. This slope is close to that expected for an electrode reaction of proton/electron ratio of $1 / 2$, which is $29.6 \mathrm{mV} / \mathrm{pH}$ at $25^{\circ} \mathrm{C}$. In addition, the number of electrons determined in the oxidation of NADH in this work was two electrons. The number of protons involved in this process should be one and a number of electrons equal to 2 for $\mathrm{pH}$ between 5.0 and 7.0, which is in accordance to proton/ electron ratio determined by other researchers. ${ }^{45}$

Table 1. Kinetic parameters for the electro-oxidation of NADH in different electrodes

\begin{tabular}{|c|c|c|c|c|c|}
\hline Electrode & Matrix & Mediator & $\mathrm{pH}$ & $\mathrm{k}_{\mathrm{obs}} /\left(\mathrm{mol}^{-1} \mathrm{~L} \mathrm{~s}^{-1}\right)$ & Reference \\
\hline GCE & - & $o$-aminophenol & 7.0 & $1.1 \times 10^{5}$ & 43 \\
\hline $\mathrm{CPE}$ & SWNT & 3,4-di-hydroxybenzaldehyde & 7.0 & $2.0 \times 10^{3}$ & 46 \\
\hline GCE & - & 2-nitro-9-fluorenone & 8.0 & $5.0 \times 10^{4}$ & 47 \\
\hline GCE & PEDOT & catechin & 7.0 & $9.8 \times 10^{3}$ & 48 \\
\hline GCE & $\mathrm{rGO}$ & CT-DNA/NiTsPc & 7.0 & $7.35 \times 10^{5}$ & this work \\
\hline
\end{tabular}

GCE: glassy carbon electrode; CPE: carbon paste electrode; SWNT: single-walled carbon nanotube; PEDOT: poly(3,4-ethylenedioxythiophene); CT-DNA: calf thymus (CT-DNA); NiTsPc: nickel tetrasulfonated phthalocyanine; rGO: reduced graphene oxide. 
Table 2. Influence of concentration of graphene with $[\mathrm{NiTsPc}]=10 \mathrm{mmol} \mathrm{L}^{-1}$ and NiTsPc with $[\mathrm{rGO}]=0.5 \mathrm{mg} \mathrm{mL}^{-1}$ of the electrochemical oxidation of NADH $\left(200 \mu \mathrm{mol} \mathrm{L}^{-1}\right)$. In both cases, $2 \mathrm{mg} \mathrm{mL}^{-1}$ of CT-DNA was used. Electrochemical measurements were performed in $0.1 \mathrm{~mol} \mathrm{~L}^{-1}$ phosphate buffer $\mathrm{pH} 7.0 . \mathrm{v}=0.05 \mathrm{~V} \mathrm{~s}^{-1}$

\begin{tabular}{lc}
\hline$[\mathrm{rGO}] /\left(\mathrm{mg} \mathrm{mL}^{-1}\right)$ & $\mathrm{I}_{\mathrm{p}} / \mu \mathrm{A}$ \\
\hline 0.50 & 1.74 \\
0.75 & 1.72 \\
1.00 & 1.64 \\
1.50 & 1.65 \\
\hline$\left[\mathrm{NiTsPc} /\left(\mathrm{mmol} \mathrm{L}^{-1}\right)\right.$ & \\
\hline 0.10 & 0.95 \\
1.0 & 2.25 \\
10.0 & 1.65 \\
\hline
\end{tabular}

NiTsPc: nickel tetrasulfonated phthalocyanine; rGO: reduced graphene oxide.

\section{Analytical characterization of the modified electrode}

In order to obtain an analytical curve for the proposed sensor, differential pulse voltammograms for different concentrations of NADH were carried out in $0.1 \mathrm{~mol} \mathrm{~L}^{-1}$ phosphate buffer at $\mathrm{pH} 7.0$, after optimizing the experimental parameters (Figure 7). The proposed sensor showed a linear response range from 1 up to $1350 \mu \mathrm{mol} \mathrm{L}^{-1}$ (inset of Figure 7) which can be expressed according to equation 7 :

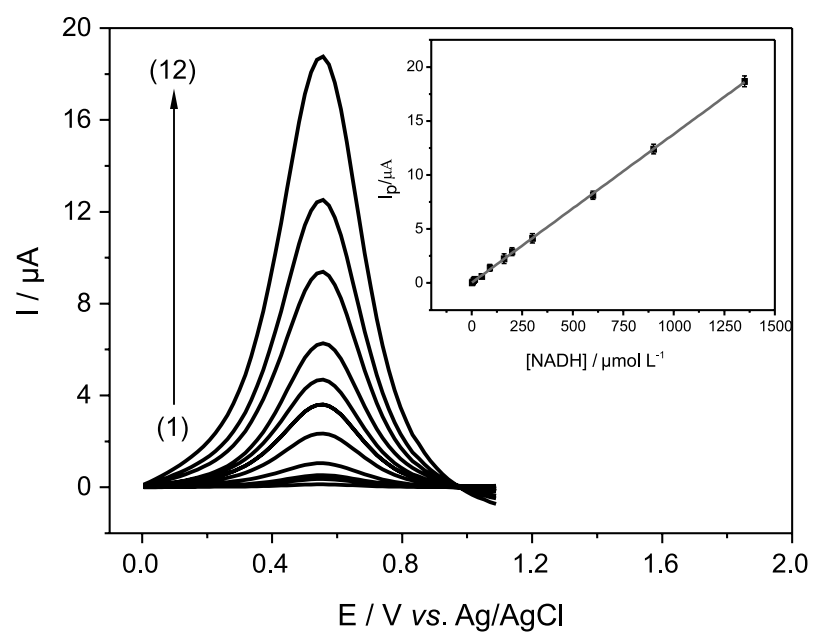

Figure 7. DPV for the NADH oxidation at the following concentrations (1) 1 , (2) 5, (3) 10, (4) 15, (5) 50, (6) 90, (7) 160, (8) 200, (9) 300, (10) 600, (11) 900 and (12) $1350 \mu \mathrm{mol} \mathrm{L} \mathrm{L}^{-1}$. Carried experiments under optimized experimental and operational parameters. Inset: calibration curve obtained from DPVs of Figure 7.

$\mathrm{I}_{\mathrm{p}}(\mu \mathrm{A})=(0.06 \pm 0.03)+(0.014 \pm 0.006)[\mathrm{NADH}](\mu \mathrm{mol} \mathrm{L}-1)$

with a correlation coefficient of 0.999 (for $n=12$ ).

A detection limit of $0.30 \mu \mathrm{mol} \mathrm{L}{ }^{-1}$ was determined using a $3 \sigma$ /slope ratio and the quantification limit was $1.0 \mu \mathrm{mol} \mathrm{L} \mathrm{L}^{-1}$ using $10 \sigma$ /slope, where $\sigma$ is the standard deviation of the mean value for ten voltammograms of the blank determined according to the IUPAC recommendations. ${ }^{49}$

Table 3. Linear range, sensitivity and LOD for the determination of NADH using different electrodes

\begin{tabular}{|c|c|c|c|c|}
\hline Electrode & $\begin{array}{l}\text { Linear range / } \\
\left.(\mu \mathrm{mol} \mathrm{L})^{-1}\right)\end{array}$ & $\begin{array}{l}\text { Sensitivity / } \\
\left(\mu \mathrm{A} \mathrm{L} \mu \mathrm{mol}^{-1}\right)\end{array}$ & $\begin{array}{c}\text { LOD / } \\
\left.(\mu \mathrm{mol} \mathrm{L})^{-1}\right)\end{array}$ & Reference \\
\hline NanoAu-MWNTs-Teflon & $10-100$ & 0.037 & NR & 1 \\
\hline Pt disk/PDAMS ${ }^{a}$ & $70-400$ & 0.00676 & 1.56 & 12 \\
\hline 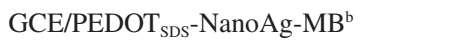 & $500-3800$ & 0.014 & high & 50 \\
\hline CESP/NADoxidase-Fc ${ }^{c}$ & $10-560$ & 0.0023 & 0.1 & 51 \\
\hline Electrode paste graphene & $5-200$ & NR & NR & 52 \\
\hline Graphite electrode/quercetin & $0.5-100$ & 0.034 & 0.15 & 53 \\
\hline Magnetic nanoparticles $\mathrm{Fe}_{3} \mathrm{O}_{4} / \mathrm{MWNTs}$ & $1-70$ & 0.0070 & 0.3 & 54 \\
\hline NanoAu/MWNT & $18-1400$ & NR & 0.5 & 55 \\
\hline Peptide diphenylalanine/MWNTs & $20-800$ & 0.00287 & 10 & 56 \\
\hline GCE/graphene & $50-1400$ & 0.013 & 20 & 57 \\
\hline Carbon black/ $/ \mathrm{Fe}_{2} \mathrm{O}_{3}$ & $10-1000$ & 0.0025 & 10 & 58 \\
\hline $\mathrm{CRDE} / \mathrm{Co}_{3} \mathrm{O}_{4}{ }^{\mathrm{d}}$ & $10-100$ & 0.0028 & 4.25 & 59 \\
\hline Graphite $/ \mathrm{SiO}_{2} / \mathrm{SnO}_{2} / \mathrm{Sb}_{2} \mathrm{O}_{5} /$ Meldola blue & $50-300$ & NR & 10 & 60 \\
\hline $\mathrm{GCE} / \mathrm{rGO}^{\mathrm{e}}$ & $10-600$ & NR & 0.33 & 61 \\
\hline GCE/PBCB/SWCNT ${ }^{\mathrm{f}}$ & $3.0-104.2$ & 0.0099 & 1.0 & 62 \\
\hline CT-DNA/NiTsPc/rGO & $1-1350$ & 0.014 & 0.3 & \\
\hline
\end{tabular}

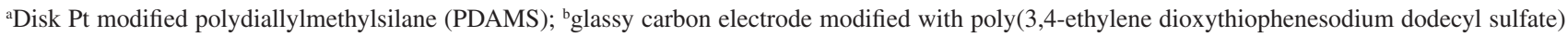
$\left(\right.$ PEDOT $\left._{\mathrm{SDS}}\right) / \mathrm{Ag}$ nanoparticle/Meldola blue; ${ }^{\mathrm{c}}$ screen-printed carbon electrode modified with NADoxidase-ferrocene enzyme; ${ }^{\mathrm{d}}$ rotating disk carbon electrode modified with $\mathrm{Co}_{3} \mathrm{O}_{4}$; ${ }^{\text {e }}$ glassy carbon electrode modified with a reduced graphene oxide (rGO); ${ }^{\mathrm{f}}$ glassy carbon electrode modified with poly (brilliant cresyl blue) (PBCB)/SWCNT: single-wall carbon nanotubes; NR: not reported; LOD: limit of detection. 
According to Table 3 it was observed that although the references 1 and 53 show higher sensitivities than the proposed sensor, it is observed that both sensors therein reported show low linear ranges. In addition, although the low limits of detection presented in references 51 and 53, the present sensor presents a wide linear response range than those therein reported. Therefore, the present sensor presents promising analytical parameters such as sensitivity, detection limit and linear range of response for NADH determination in comparison to many reported works in the literature (Table 3). Such good analytical performance can be attributed to the efficiency of the electron transfer between the CT-DNA/NiTsPc/rGO electrode surface and NADH, due to the good electrocatalytic effect of the composite.

Even when stored at room temperature, no significant change in the sensor response was observed for at least two months. The modified electrode presented good repeatability for the NADH determination. The relative standard deviation (RSD) for 10 determinations of $50 \mu \mathrm{mol} \mathrm{L} \mathrm{L}^{-1} \mathrm{NADH}$ was $2.33 \%$. Additionally, a series of 10 sensors were prepared in the same manner and tested in $0.1 \mathrm{~mol} \mathrm{~L}^{-1}$ phosphate buffer ( $\mathrm{pH} 7.0$ ) containing $50 \mu \mathrm{mol} \mathrm{L}^{-1}$ $\mathrm{NADH}$, and responses with a RSD of $3.10 \%$ were observed. These results indicate that the CT-DNA/NiTsPc/rGO/GCE has good repeatability and reproducibility, probably due to the ability of rGO and CT-DNA to fix the NiTsPc complex on the electrode surface in a reproducible and accurate way.

The selectivity of the CT-DNA/NiTsPc/rGO modified electrode was evaluated by examining the influences of several possible interfering substances on the detection of $50 \mu \mathrm{mol} \mathrm{L} \mathrm{L}^{-1} \mathrm{NADH}$. Solutions of these compounds were freshly prepared in the same conditions of NADH (0.1 mol L-1 PBS at pH 7.0). The electrochemical results (Table S1) indicated that 100-fold higher concentrations of different species (sodium chloride, sodium bicarbonate, potassium chloride, potassium phosphate dibasic trihydrate, magnesium chloride hexahydrate, ascorbic acid, uric acid, dopamine, glucose and vitamin B6) did not interfere in the NADH determination.

\section{Application to samples and recovery tests}

For an additional analysis on the accuracy of the developed method and the interference of the matrices, analytical recovery experiments were performed by adding known amounts of NADH $\left(3,5\right.$ and $\left.10 \mu \mathrm{mol} \mathrm{L}^{-1}\right)$ in two samples in triplicate (urine samples). The percentage of recovery was calculated by comparing the concentration obtained from the samples with actual and added concentrations. The recoveries for the urine samples are shown in Table 4. It can be clearly observed that there is no influence of the matrices on the developed sensor.

Table 4. Recovery values of NADH obtained for two urine samples $(n=5)$

\begin{tabular}{lcccc}
\hline Sample & $\begin{array}{c}\text { NADH } \\
\text { added / } \\
\left(\mu \mathrm{mol} \mathrm{L}^{-1}\right)\end{array}$ & $\begin{array}{c}\text { NADH } \\
\text { expected / } \\
(\mu \mathrm{mol} \mathrm{L})^{-1}\end{array}$ & $\begin{array}{c}\text { NADH } \\
\text { found / } \\
\left(\mu \mathrm{mol} \mathrm{L}{ }^{-1}\right)\end{array}$ & $\begin{array}{c}\text { Recovery / } \\
\%\end{array}$ \\
\hline Urine A & 3.00 & 3.00 & $2.98 \pm 0.03$ & 99.33 \\
& 5.00 & 5.00 & $5.01 \pm 0.08$ & 100.20 \\
Urine B & 10.00 & 10.00 & $10.05 \pm 0.05$ & 100.50 \\
\hline & 3.00 & 3.00 & $2.97 \pm 0.10$ & 99.00 \\
& 10.00 & 10.00 & $9.85 \pm 0.05$ & 98.50 \\
\hline
\end{tabular}

NADH: $\beta$-nicotinamide adenine dinucleotide.

\section{Conclusions}

This work demonstrated that glassy carbon electrode modified with CT-DNA/NiTsPc/rGO is a feasible alternative for the analytical determination of NADH. Optimization of the experimental conditions yielded a detection limit and sensitivity for NADH, respectively, of 0.3 and $0.014 \mu \mathrm{A} \mathrm{L} \mu \mathrm{mol}^{-1}$. This sensor showed good repeatability for the measurements and electrode preparation, evaluated in terms of relative standard deviation, of 2.33 and $3.10 \%$, respectively. The proposed sensor was applied in artificial urine samples and the average recovery for these samples was $99.5 \pm 0.5 \%$. In this sense, this work demonstrated that the glassy carbon electrode modified with CT-DNA/ $\mathrm{NiTsPc/rGO}$ is a sensitive and stable sensor showing great potential for NADH determination.

\section{Supplementary Information}

Supplementary information is available free of charge at http://www.jbcs.sbq.org.br as a PDF file.

\section{Acknowledgments}

The authors are grateful to Conselho Nacional de Desenvolvimento Científico e Tecnológico (CNPq), Rede Mineira de Química, Fundação de Amparo à Pesquisa do Estado de Minas Gerais (FAPEMIG), INCT-Bio and Fundação de Amparo à Pesquisa do Estado do Maranhão (FAPEMA).

\section{References}

1. Saleh, F. S.; Rahman, M. R.; Okajima, T.; Mao, L.; Ohsaka, T.; Bioelectrochemistry 2011, 80, 121. 
2. You, J.; Jeon, S.; Electrochim. Acta 2011, 56, 10077.

3. Radoi, A.; Compagnone, D.; Bioelectrochemistry 2009, 76, 126.

4. Duboc, D.; Toussaint, M.; Renault, G.; Polianski, J.; Guerin, F.; Pocidalo, J. J.; Degeorges, M.; Arch. Mal. Coeur Vaiss. 1987, 80, 236.

5. Margolis, S. A.; Schaeffer, R.; Clin. Chem. 1976, 22, 1179.

6. Tang, L.; Lei, X.; Zeng, G.; Liu, Y.; Peng, Y.; Wu, M.; Zhang, Y.; Liu, C.; Li, Z.; Shen, G.; Spectrochim. Acta, Part A 2012, 99, 390.

7. Dilgin, Y.; Dilgin, D. G.; Dursun, Z.; Gökcel, H. I.; Gligor, D.; Bayrak, B.; Ertek, B.; Electrochim. Acta 2011, 56, 1138.

8. Dewitt, C. M.; Moore, K. H.; FASEB J. 1995, 9, A476.

9. Omar, F. S.; Duraisamy, N.; Ramesh, K.; Ramesh, S.; Biosens. Bioelectron. 2016, 79, 763.

10. Zanardi, C.; Ferrari, E.; Pigani, L.; Arduini, F.; Seeber, R.; Chemosens. 2015, 3, 118.

11. Shan, C.; Yang, H.; Han, D.; Zhang, Q.; Ivaska A.; Niu, L.; Biosens. Bioelectron. 2010, 25, 1504.

12. Jiménez, A.; Armada, M. P. G.; Losada, J.; Villena, C.; Alonso, B.; Casado, C. M.; Sens. Actuators, B 2014, 190, 111.

13. Li, Z.; Huang, Y.; Chen, L.; Qin, X.; Huang, Z.; Zhou, Y.; Meng, Y.; Li, J. Huang, S.; Liu, Y.; Wang, W.; Xie, Q.; Yao, S.; Sens. Actuators, B 2013, 181, 280.

14. Yang, W.; Ratinac, K. R.; Ringer, S. P.; Thordarson, P.; Gooding, J. J.; Braet, F.; Angew. Chem., Int. Ed. 2010, 49, 2114.

15. Kuila, T.; Bose, S.; Khanra, P.; Mishra, A. K.; Kim, N. H.; Lee, J. H.; Biosens. Bioelectron. 2011, 26, 4637.

16. Liu, Y.; Dong, X.; Chen, P.; Chem. Soc. Rev. 2012, 41, 2283.

17. Zhong, J.; Fan, Y.; Wang, H.; Wang, R.; Fan, L.; Shen, X.; Shi, Z.; Electrochim. Acta 2013, 113, 653.

18. Ferreira, G. M. M.; Oliveira, F. M.; Leite, F. R. F.; Maroneze, C. M.; Kubota, L. T.; Damos, F. S.; Luz, R. C. S.; Electrochim. Acta 2013, 111, 543.

19. Sharifi, E.; Salimi, A.; Shams, E.; Bioelectrochemistry 2012 , $86,9$.

20. Premkumar, T.; Geckeler, K. E.; Prog. Polym. Sci. 2012, 37, 515.

21. Castro, J. G. M.; Ferreira, G. M. M.; Oliveira, F. G.; Damos, F. S.; Luz, R. C. S.; J. Electroanal. Chem. 2014, 732, 93.

22. Vilela Jr., E. T.; Carvalho, R. C. S.; Yotsumoto Neto, S.; Luz, R. C. S.; Damos, F. S.; J. Electroanal. Chem. 2015, 752, 75.

23. Damos, F. S.; Luz, R. C. S.; Tanaka, A. A. In Electrochemistry of N4 Macrocyclic Metal Complexes, vol. 2; Zagal, J. H.; Bedioui, F., eds.; Springer International Publishing: New York, 2016, p. 201.

24. Lever, A. B. P.; J. Porphyrins Phthalocyanine 1999, 3, 488.

25. Zagal, J. H.; Griveau, S.; Silva, J. F.; Nyokong, T.; Bedioui, F.; Coord. Chem. Rev. 2010, 254, 2755.

26. Zhou, X.; Wang, X.; Wang, B.; Chen, Z.; He, C.; Wu, Y.; Sens. Actuators, B 2014, 193, 340.
27. Pakapongpan, S.; Mensing, J. P.; Phokharatkul, D.; Lomas T.; Tuantranont, A.; Electrochim. Acta 2014, 133, 294.

28. Bard, A. J.; Faulkner, L. R.; Electrochemical Methods: Fundamentals and Applications, $2^{\text {nd }}$ ed.; John Wiley \& Sons, Inc.: Hoboken, New Jersey, 2001, p. 833.

29. Sabatani, E., Rubinstein, I.; J. Phys. Chem. 1987, 91, 6663.

30. Haglock-Adler, C. J.; Hurley, A.; Strathmann, F. G.; Clin. Biochem. 2014, 47, 80.

31. Laube, N.; Mohr, B.; Hesse, A.; J. Cryst. Growth 2001, 233, 367.

32. Low, C. T. J.; Walsh, F. C.; Chakrabarti, M. H.; Hashim, M. A.; Hussain, M. A.; Carbon 2013, 54, 1.

33. Frogley, M. D.; Wang, C.; Cinque, G.; Barber, A. H.; Vib. Spectrosc. 2014, 75, 178.

34. Berríos, C.; Cárdenas-Jirón, G. I.; Marco, J. F.; Gutiérrez, C.; Ureta-Zañartu, M. S.; J. Phys. Chem. A 2007, 111, 2706.

35. Bertoncello, P.; Peruffo, M.; Colloids Surf., A 2008, 321, 106.

36. Verma, D.; Dash, R.; Katti, K. S.; Schulz, D. L.; Caruso, A. N.; Spectrochim. Acta, Part A 2008, 70, 1180.

37. N4-Macrocyclic Metal Complexes; Zagal, J. H.; Bedioui, F.; Dodelet, J. P., eds.; Springer: New York, 2006.

38. Asadi, M.; Safaei, E.; Ranjbar, B.; Hasanib, L.; New J. Chem. 2004, 28, 1227.

39. Pasternack, R. F.; Schaefer, K. F.; Hambright, P.; Inorg. Chem. 1994, 33, 2062.

40. Aghaie, M.; Naderi, F.; Monajjemil, M.; Aghaie, H.; Safari, N.; Jamaat, P. R.; J. Phys. Theor. Chem. 2007, 3, 27.

41. Sousa, A. L.; Santos, W. J. R.; Luz, R. C. S.; Damos, F. S.; Kubota, L. T.; Tanaka, A. A.; Tanaka, S. M. C. N.; Talanta 2008, 75, 333 .

42. Luz, R. C. S.; Moreira, A. B.; Damos, F. S.; Tanaka, A. A.; Kubota, L. T.; J. Pharm. Biomed. Anal. 2006, 42, 184.

43. Nassef, H. M.; Radi, A.; O'Sullivan, C. K.; Electrochem. Commun. 2006, 8, 1719.

44. Lima, P. R.; Santos, W. J. R.; Oliveira, A. B.; Goulart, M. O. F.; Kubota, L. T.; Biosens. Bioelectron. 2008, 24, 448.

45. Elving, P. J.; Bresnahan, W. T.; Moiroux, J.; Samec, Z.; Bioelectrochem. Bioenerg. 1982, 9, 365.

46. Antiochia, R.; Lavagnini, I.; Magno, F.; Anal. Bioanal. Chem. 2005, 381, 1355.

47. Mano, N.; Kuhn, A.; J. Electroanal. Chem. 1999, 477, 79.

48. Vasantha, V. S.; Chen, S.; Electrochim. Acta 2006, 52, 665.

49. Analytical Methods committee; Analyst; 1987, p. 199.

50. Balamurugan, A.; Ho, K.; Chen, S.; Huang, T.; Colloids Surf., A 2010, 362, 1.

51. Creanga, C.; Murr, N. E.; J. Electroanal. Chem. 2011, 656, 179.

52. Gasnier, A.; Pedano, M. L.; Rubianes, M. D.; Rivas, G. A.; Sens. Actuators, B 2013, 176, 921.

53. Dilgin, Y.; Kizilkaya, B.; Dilgin, D. G.; Gökçel, H. I.; Gorton, L.; Colloid Surf., B 2013, 102, 816. 
54. Teymourian, H.; Salimi, A.; Hallaj, R.; Biosens. Bioelectron. 2012, 33, 60 .

55. Tiwari, I.; Gupta, M.; Mater. Res. Bull. 2014, 49, 94.

56. Yuan, J.; Chen, J.; Wu, X.; Fang, K.; Niu, L.; J. Electroanal. Chem. 2011, 656, 120.

57. Guo, K.; Qian, K.; Zhang, S.; Kong, J.; Yu, C.; Liu, B.; Talanta 2011, 85, 1174.

58. Kim, Y. H.; Kim, T.; Ryu, J. H.; Yoo, Y. J.; Biosens. Bioelectron. 2010, 25, 1160.
59. Chen, C.; Chen, Y.; Lin, M.; Biosens. Bioelectron. 2012, 42, 379.

60. Canevari, T. C.; Vinhas, R. C. G.; Landers, R.; Gushikem, Y.; Biosens. Bioelectron. 2011, 26, 402.

61. Tabrizi, M. A.; Azar, A. J.; Varcani, J. N.; Anal. Biochem. 2014, 460, 29.

62. Yang, D. W.; Liu, H. H.; Biosens. Bioelectron. 2009, 25, 733.

Submitted: November 30, 2016

Published online: February 15, 2017 